\title{
Mette Mechlenborg
}

\section{Hjemme i globaliseringen}

I nærværende artikel er det min hensigt at sætte fokus på den aktuelle dyrkelse af hjemmet, som har pustet liv i en diskussion om hjemmets rolle i globaliseringsteorierne. I dag synes udfordringen ikke at forstå globaliseringen over for det forankrede hverdagsliv, men at forsøge at etablere en dialog mellem de to.

Ved at sætte begrebet hjem centralt i forhold til teorier om mobilitet, modernisering og globalisering, vil denne artikel sætte fokus på kløften mellem stereotype opfattelser af globaliseringen og indgroede myter om hjem og hverdagsliv. Teoretisk og metodisk er artiklen placeret i feltet mellem boligforskning, kulturstudier og globaliseringsforskningen. Med udgangspunkt i Marshall Bermans modernitetsopfattelse og Mieke Bals tværkulturelle teori om "rejsende koncepter" gennemgås en række kanoniserede ideer om hjem og globalisering, idet hensigten er at åbne op for en mere nuanceret, tidssvarende definition af det globaliserede hjem. Af referencer kan nævnes Zygmunt Bauman, David Morley, John Tomlinson og Agnes Heller.

Søgeord: Globalisering, hjem, hverdagsliv, mobilitet, teori. 
$\mathrm{F}$ lere tænkere har anført, at dyrkelsen af bolig, hjem og fædreland i tv, kunst og politik, som har præget indgangen til det 21. århundrede, kan ses som en naturlig modreaktion til den omsiggribende globalisering. Som Zygmunt Bauman formulerer det i Globalisering. De menneskelige konsekvenser er vi i dag "alle i bevægelse, enten vi vil det eller ej, planlagt eller nødtvunget. Vi bevæger os, også selv om vi rent faktisk bliver hvor vi er: immobilitet er ikke en realistisk valgmulighed i en verden af permanent forandring .. for os alle er "globalisering denne verdens uregerlige skæbne" (1998:7-8). Men tryk danner modtryk, og som modsvar til kravet om forandring, bevægelse og frihed, higer vi nu efter forankring, historie og en fast grund under fødderne.

Alene i Danmark har interessen for hjemmet kunnet spores i kunst- og designudstillinger som "Hjemme igen", ARKEN (2002), "Home sweet Home", Århus Kunstmuseum (2003), "Honey I'm Home" på Danmarks Designcenter (2006) og "Home sweet Home", Statens Museum for Kunst (2007). Også i romaner og noveller har forfattere taget hjemmet til sig som et særligt sted for intimitet, familiesagaer og sandheder om mennesket. Blandt andet valgte Klaus Rifbjerg at dedikere en roman til sit barndomshjem, da Gyldendal i 1999 bad ham skrive om en begivenhed eller et sted, der havde haft størst betydning for ham i det forrige århundrede (Huset 1999). Hjemmet er også, hvad der i et årti er blevet eksponeret i magasiner, på messer og ikke mindst på tv. I hjemdyrkelsens storhedstid kunne man tælle op til 12 danskproducerede bolig- og indretningsprogrammer på dansk sendeflade, foruden en række udenlandske programmer om alt fra have, mad, familie, børneopdragelse og gør-det-selv. Interessen for bolig og hjem afspejles ligeledes i danskernes privatforbrug: De fleste af os har aldrig haft så mange penge til rådighed, som vi har nu, og en stor del af dem bruges på vores hjem. I dag går ca. 20 procent af vores privatforbrug til boligydelser mod bare 5 procent i 1948. Samtidig er værdien af danskernes gør-det-selv-arbejde i hjemmet steget fra 26 mia. kroner til 41 mia. kroner siden 1994 (Forbrugsundersøgelsen, Danmarks Statistik ). ${ }^{1}$

Omdrejningspunktet i denne artikel er de akademiske refleksioner, der er fulgt $\mathrm{i}$ kølvandet på den aktuelle interesse for hjem, og som igen har pustet liv i diskussionen om hjemmets rolle i den moderne selvforstålse, her specielt i forhold til globaliseringen og dens konsekvenser. Groft skitseret kan man sige, at siden det moderne gennembrud har hjemmet været stridspunkt for to uforenelige moderne ideologier: Dels en fremtidsoptimistisk fløj, som anskuer hjemmet som symbolet på tradition, regression og tilbagetrækning fra det autentiske moderne liv, hvorfor hjemmet er noget, som man definitivt må forlade for at kunne dedikere sig helt og holdent til den moderne tilværelse. En ideologi, som formuleres af den tidlige kulturelle avantgarde, futuristerne og de toneangivende modernitetstænkere og -arkitekter, heriblandt Charles Baudelaire, Adolf Loos, Walter Benjamin og Le Courbusier. Dels en modernitetsskeptisk fløj, der betragter det moderne projekt som mislykket og fremmedgørende, og derfor finder det nødvendigt at prøve at genskabe noget af den menneskelig- 


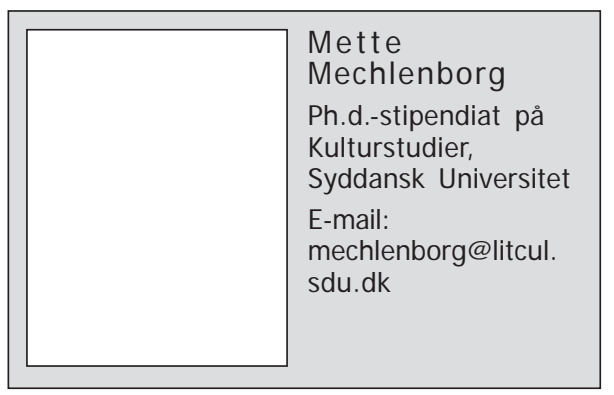

hed, der er gået tabt. Denne ideologi trækker tråde tilbage til Art\&Craftbevægelserne, ideologien bag den engelske have-by, ${ }^{2}$ og ligger som et ekko i mange modernitetskritiske strømninger op igennem forrige århundrede, blandt andet hos surrealisterne. ${ }^{3}$ I begge tilfælde forudsættes en dikotomi mellem helhedstænkning, mening og forankring på den ene side, og det dynamiske og evigt grænseoverskridende moderne liv på den anden. Midt i mellem disse fløje positioneres hjemmet som et moderne ambivalent fænomen, hvor nostalgien går hånd $\mathrm{i}$ hånd med euforien, udlængsel med hjemve.

Det er min antagelse, at denne ambivalens i forhold til moderniteten kan bruges som indstigning til en dybere forståelse af globaliseringsdiskussionerne i dag, og endvidere, kaste lys over de dogmer og myter, der stadig knytter sig til den moderne vestlige forståelse af hjem. For eksempel har tænkere som David Morley (2000), Krishan Kumar (1994), John Tomlinson (1999), Nikos Papastergiadis (1998) og Agnes Heller (1995) påpeget, at den vestlige tænkning er strandet i en stereotyp opfattelse af, hvad modernitet og globalisering er, idet denne tænkning undervurderer den betydning hjemmet, familien og dagligdagens trummerum stadig har for størstedelen af den globaliserede verdens befolkning.

I det følgende er det min hensigt at reflektere over konceptet "hjem" i perspektivet af de kanoniserede erfaringer med den moderne og senmoderne verden. Tesen er, at diskussionen i dag ikke så meget handler om forskellen mellem globalisering og hjem, som om forbindelsen mellem disse. Eller sagt således: Ved at sætte fokus på de teoretikere, der anskuer konceptet hjem i et globaliseringsperspektiv, er det intentionen at skabe en dialog mellem globaliseringsteorierne og traditionel hjemforskning, mellem kravet om mobilitet på den ene side og behovet for forankring på den anden. Mine teoretiske omdrejningspunkter er foruden mediesociologen David Morleys Home Territoriums (2000), Agnes Hellers "Where are we at home?" (1995) og Marshall Bermans beskrivelse af splittelsen i den moderne erfaring i All That Is Solid Melts Into Air (1982/ 1988), mens globaliseringsforståelsen primært er hentet fra Zygmunt Baumans Globaliseringen. De menneskelige konsekvenser (1998). Metodisk læner jeg mig op af den hollandske narratolog Mieke Bals koncept-baserede metodik, som beskrives i Travelling Concepts in Humanities, 2000. 


\section{Fra ambivalens til splittelse}

En af de store modernitetstænkere er den amerikanske Marshall Berman. I hovedværket All That Is Solid Melts Into Air forsøger han at indkredse den historiske moderne erfaring. Med henvisning til Karl Marx' parole om, at "alt hvad, der er solidt smelter til luft", definerer Berman det at være moderne som at finde sig selv i "omgivelser, der lover os eventyr, magt, nydelse, forandring, transformation af os selv og verden - og som på samme tid truer med at destruere alt, hvad vi har, alt, hvad vi ved, og alt, hvad vi er“ (1982/1988:15, min overs.). Bermans modernitetsteori kan desuden bruges at kaste lys over den indbyggede konflikt, der ligger i den moderne selvforståelse, og her særligt i det konflikterende forhold mellem forankring og forandring, hjem og mobilitet.

Moderniteten skal ifølge Berman forstås som en dialektisk proces mellem modernisering på den ene side og modernisme på den anden. Moderniseringen repræsenterer de nye opfindelser, industrialiseringen, kapitalismen og nye sociale processer, der opstår på grund af disse opfindelser, herunder nye kommunikations- og sundhedssystemer, job-, uddannelse-, familie- og boligforhold, som ændrer sig under moderniseringsprocessen. Modernismen er på den anden side ideer, visioner, ofte kunst og litteratur, og fungerer som det spejl, hvori moderniseringen forstås og giver mening. Modernitetserfaringen er altså gensidig afhængig af de sociale processer, som gør det muligt for os at udvikle og ændre vores konkrete levevilkår, og på den anden side de ideer, visioner og forklaringer, der er tilgængelige for at kunne forstå disse processer. Bermans tese er imidlertid, at moderniseringen i dag kun sjældent relaterer til modernismen og vice versa. Selve ideen om det moderne er blevet fragmenteret og har mistet sin sammenhængskraft, siger han, hvilket har betydet at modernismen (idéerne, visionerne og forklaringsmodellerne) ikke længere evner at organisere og skabe mening i menneskets liv (1988:17). Vi har med andre ord svært ved at finde forklaringer, der matcher de problemstillinger, vi slås med i vores dagligdag, mens de forklaringer, der er tilgængelige, synes tilpas abstrakte, lukkede og autonome til at kunne relatere til noget andet end det abstrakte, fragmentariske niveau i sig selv.

I artiklen "The invention of Everyday Life" (1999/2000) reflekterer den engelske litteraturprofessor Rita Felski over brugen af begrebet "hverdag". Hendes pointe er, at "hverdag" som begreb ofte bruges med en indforstået selvfølgelighed til trods for, at det "sjældent lægges under mikroskopet og undersøges som begreb“. Dette medfører efter hendes overbevisning både teoretiske og metodiske problemer: "Som alle andre analytiske termer organiserer det verden ifølge bestemte antagelser og kriterier" (min overs., 1999-2000:15). Felski peger i forlængelse heraf på behovet for en mere stringent akademisk refleksion over de begreber, som de humanistiske discipliner anvender. Den hollandske kulturanalytiker og narratolog Mieke Bal lancerer i Travelling Concepts in Humanities (2002) en koncept-baseret metode, som netop tager ud- 
gangspunkt i begrebet eller konceptet, sådan som det bruges på tværs af de akademiske discipliner, medier og i hverdagskulturen. Bals metode handler om, at man i mindre grad skal spørge til, hvad konceptet betyder og i højere grad spørge til, hvad det bruges til, og hvad det gør (2002:11 og 25). Dette performative niveau forbinder konceptets betydning med dets brug: "Mens [vi] arbejder på at definere, hvad et bestemt begreb betyder, får vi indsigt i, hvad det kan gøre.“ (min overs., 2002:11).

Sammenholdt med Bermans distinktion mellem modernisme og modernisering kan man sige, at hensigten er at anskue hjemmet som en kognitiv figur, der er "del af en struktur, et systematisk sæt af distinktioner", jf. Bals definition (2002:22). Således anskues hjemmet som et sæt af værdier og dogmer, der ikke blot strukturerer vores hverdagsliv, men som er med til at forme vores forståelse af verden og os selv i denne verden. Ikke at forstå, at hjem som sådan kan reduceres til en enkelt tankefigur. Til da er hjemmet et alt for kompleks begreb, der ændrer betydning afhængig af om referencen går på den private bolig eller fædrelandet, familien, slægten, barndomshjemmet, hjemmet i psykoanalysen, sociologien, arkitekturen, litteraturen, globaliseringsteorierne etc. Alligevel kan man hævde, at der på tværs af disse brug har domineret en overordnet opfattelse af hjemmet som del af en grundlæggende oppositionstænkning, hvor altså forankring modstilles forandring, stilstand mobilitet, tryghed frihed, og at denne oppositionstænkning er tæt forbundet med myter om hjem, såvel som myter om det moderne. Det vil sige, at vores opfattelse af hjem er splittet mellem en ideologi, der med udgangspunkt i globaliseringsteorierne insisterer på en "verden af permanent forandring" (jf. Bauman), og ældgamle myter om hjemmet som meningsfuldt sted for forankring og rodfæstelse, mellem overordnede forklaringsmodeller og hverdagslogik, mellem modernisering og modernisme.

\section{Konceptet hjem}

Hjemmet som begreb spiller en vigtig rolle i den vestlige tænkning, hvor det traditionelt er blevet tillagt en række positive karakteristika. Disse kommer mestendels til udtryk i hverdagskulturen. Når vi taler om hjemmebag, hjemmelavet, hjemland, hjemegn, hjemvé eller for den sags skyld hip-hop kulturens slangudtryk "homie" og "homeboy", så opfatter vi disse fænomener som mere meningsfulde og autentiske, alene fordi de knytter sig til hjemmets sfære. Mere eksplicit er valoriseringen i mottos som "ude godt, hjemme bedst", "hjem kære hjem" og andre floskler, som stadig den dag i dag afspejles i sociologi og statistik. For eksempel i antallet af unge danskere, der flytter tilbage til deres fødeegn eller til den boliggenre, som de er opvokset i, når de etablerer sig og får børn. ${ }^{4}$

Dette træk ved hjemmet går igen i utallige eventyr, som vi har fået fortalt som små, og som vi genfortæller for vores egne børn. I de fleste eventyr er hjemmet det, som helten forlader for at begive sig ud i verden, og det han 
slutteligt vender tilbage til, når farerne er overvundet og fristelserne overkommet. Hjemmet er det naturlige begyndelsespunkt og det naturlige slutpunkt, og er meget enkelt indfanget i den simple, men slagkraftige litterære model hjemme-ude-hjemme. Naturligvis kan man indvende, at rejsen er det interessante i eventyret. Primært fordi rejsen er den eneste fristelse helten og de fleste mennesker - ikke kan modstå. Helten må ud i verden og opleve det nye og ukendte. Pointen er dog den samme: Uanset hvor eksotisk, interessant og udviklende rejsen er, og uanset hvor berigende den forekommer, så er én ting sikkert, og det er, at helten unægtelig vil drages tilbage mod hjemmet. For i de fleste eventyr lyder moralen, at i forhold til hjemmets magi blegner alle glæder ved rejsen. I denne mytologi symboliserer hjemmet det, der bringer eventyret, så vel som livet tilbage til sit udgangspunkt i en naturlig, cyklisk bevægelse, illustrerende at livet må ende, hvor det begyndte. Den store amerikanske hjemkomstmyte Troldmanden fra $\mathrm{Oz}$ (bedst kendt i Victor Flemings filmatisering fra 1939 med Judy Garland i hovedrollen) demonstrerer denne tidløse konvention om hjemmets magi over rejsen. Som mantraet lyder fra Dorothys mund, så er der intet sted som hjemme!

Ifølge den danske filosof Lars-Henrik Schmidt kan denne myte spores tilbage til den vestlige civilisations grundlæggelse. I artiklen "Hjemløshed" (1990/ 2000) undersøger han to religiøse grundtekster repræsenteret ved den græskantikke fortælling, Homers Odysseen og Mosebøgerne, som ifølge ham er karakteristisk for den jødiske kulturarvs hjem-mytologi. I begge tekster dramatiseres hjemmet som en metafysisk referent, mennesket strukturerer sin tilværelse omkring. For Odysseus' vedkommende, fordi han efter 20 års strabadser og problemer endelig vender hjem til sin fødeegn Ithaka. Pointen med myten er, at hjem må han, for først her ophører kaos og kosmos genoprettes. Hjemkomsten symboliserer (gen)indsættelse af orden og stabilitet $\mathrm{i}$ verdenen, og i forhold til disse metafysiske instanser er Odysseus eget liv blot en lille brik i et større spil. Jøden i Mosebøgerne vender derimod aldrig hjem, men er dømt til en skæbne som den evigt rejsende. Alligevel har den jødiske kulturarvs grundlæggende hjem-længsel dog et vigtigt træk tilfælles med den græske kulturarvs hjemkomst-eufori: Også her er hjemmet målet for rejsen, og her alle længsler og drømme er rettet: Længslen efter hjemkomsten giver det jødiske folk en retning og en mening i livet, akkurat som hjemmet strukturerer Odysseus' færd gennem verden. Hjemmet er nemlig beviset på Gud(ernes) eksistens, på at der er en orden derude, som vil vise sig, hvis man anstrenger sig og søger hjem(ad).

\section{Den moderne helt vender aldrig hjem}

Selv om mange mennesker stadig lever og forstår deres liv som et eventyr, der nødvendigvis må ende, hvor det begyndte, så ligger denne forklaringsmodel i konkurrence med mere moderne forestillinger om, hvordan livet hænger sammen. Som mange modernitetsforskere vil sige, så ændrede det moderne gen- 
nembrud nemlig vores forhold til dikotomien rejsen over for hjemmet. Det er i hvert fald påfaldende, at det moderne gennembrud generelt beskrives som en tid, hvor den traditionelle, cykliske verden forenklet i hjemme-ude-hjemmemodellen, led sin undergang og mennesket trådte ud af fortiden. Det er bl.a. pointen i sociolog Ferdinard Tönnies beskrivelse af overgangen fra lillebyens intime relationer i gemeinschaft, til storbyens sælger-kunde forhold i gesellschaft (Gemeinschaft und Gesellschaft 1887), og i sociologen Georg Simmels beskrivelser af vilkårene i den nye storby (Storbyerne og det åndelige liv 1904).

Ambivalensen i disse værker, som på den ene side hylder mulighederne ved det nye, men begræder tabet af det gamle, går igen i mange af den tidlige modernismes værker. Den er ifølge Berman også et af de mest karakteristiske træk ved den tidlige moderne erfaring, specielt som den kommer til udtryk hos en af de første til at definere det nye, nemlig den franske 1800-tals digter og kritiker, Charles Baudelaire. Baudelaires mest kendte litterære figur, flanøren, som var gennemgående i hele forfatterskabet, er et by-menneske, der forbander den tid han bliver nød til at spendere hjemme, når han i stedet kan flanere rundt i gaderne i Paris, observere og kategorisere det nye og suge til sig af indtryk og sanseoplevelser (se eksempelvis Paris Sleen udgivet posthum 1868). Når flanøren af mange kulturforskere betegnes som den første arketypiske moderne helt, så er det fordi, flanøren indtager en heroisk position i forhold til moderniteten. Flanøren tager den nye verden på sig uden at kny og uden at begræde tabet af hjemmet som yderste reference. Det er som følge heraf, at flanøren bliver indbegrebet af en anti-hjem-ideologi: Hans insisteren på udelivet implicerer en opfattelse af hjemmet som symbolet på - om ikke det antimoderne - så i det mindste alle de egenskaber, man må fralægge sig for overhovedet at være modtagelig over for moderniteten. Med andre ord: Forudsætningen for at være moderne er, at man definitivt forlader hjemmet og overgiver sig til rejsen; til det evigt foranderlige, udviklende, men også rastløse og rodløse. Det er, hvad Baudelaire gør med sin flanør, hvad Knut Hamsun senere gjorde med den anonyme hovedperson i Sult (1890), og hvad den amerikanske beatforfatter Jack Kerouac eksemplificerer i sin roman On the Road (1955), som er én lang afsked med hjemmet i både konkret og metaforisk forstand. I modsætning til den traditionelle helt, som uundværligt drages mod hjemmet, når rejsen mister sin magi, så er den moderne helt uden håb om hjemkomst. Han dedikerer sig helt og holdent til rejsen og forsøger at leve med hjemveen og den rodløshed, som af og til sætter sig igennem.

\section{Skabelsen af det borgerlige hjem}

Denne dramatiske afsked med hjemmet som forklaringsmodel går igen i mange tidlige moderne værker, som i arkitekturmanifester og modernitetsbeskrivelser, og den knyttes mange steder sammen med en kritik af en forankringsproces, der er lige så tæt sammenknyttet med det moderne gennembrud, nemlig skabelsen det borgerlige hjem. For de fleste forskere er det moderne hjem en 
social konstruktion, der voksede ud af de borgerlige idealer om privat ejendomsret, kapitalisme og selvbestemmelsen. Derfor er mange af de egenskaber, historikere og kultursociologer trækker frem, når hjemmet defineres - det private rum, kernefamilien, komforten og adskillelse af arbejde og fritid egenskaber, der knytter sig til den moderne selvforståelse (blandt andet behandlet af Michel Lefebvre, Phillipe Ariès, Ovar Löfgren m.fl). Den tyske kritiker og forfatter Walter Benjamin siges at være en af de første til at pege på sammenhængen mellem det borgerlige hjem og det moderne samfund. I hans kritiske artikel "Louis-Philip, oder das Interieur" (1939) forlyder det, at det var i starten af 1800-tallet, at "beboelsesrummet blev adskilt fra arbejdsrum-

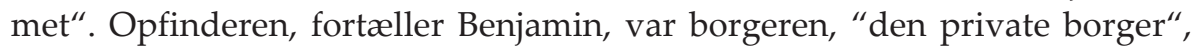
som grundet sin ansvarsfulde rolle i skabelsen af det frie, kapitalistiske og demokratiske samfund havde behov for et "interiør", hvor han kunne glemme både sociale og økonomiske problemer og være sig selv. Et rum, der ikke blot skulle få borgeren til at føle sig "distanceret i tid og rum", fortsætter han, men som også repræsenterede "en verden ... der var bedre." (Benjamin 1939/ 1983:167-169, min overs.).

Man kan argumentere for, at med det borgerlige hjem blev det metafysiske hjem sekulariseret. Det, der førhen havde stået uden for mennesket og menneskets rækkevidde, blev nu del af den konkrete, faktiske og tredimensionale verden. Ideen om hjem blev konkretiseret. Hermed overgik dikotomien mellem hjemmet og rejsen fra at være et ærinde mellem Gud(erne) og mennesket til at blive et mellemværende menneskene imellem: Eller mellem borgerne på den ene side og den kulturelle avantgarde på den anden, der anså det borgerlige hjem som symbolet på tradition, tilbagetrækning, stilstand og i sidste ende-døden. ${ }^{5}$

Men som forskere senere har påpeget, så var de opfindelser, som i sin tid muliggjorde skabelsen af det borgerlige hjem, de samme, som senere førte konstruktionen mod en fragmentering. Sociologen Krishan Kumar ekkoer en række teoretikere, når han hævder, at det lille paradisiske hjem af mor, far og barn var for snævert og for sårbart til at modstå de ændringer i samfund og kultur, som moderniseringen førte med sig, og som efterhånden invaderede hjemmet fra alle sider (1994). For det første var atomiseringen af middelalderens store husholdning i kernefamilien kun en overgangsfase mod den generelle fokusering på individet, som i dag har forvandlet familien til et sæt af selvstændige individer, der i stedet for at arbejde for et fælles mål søger efter deres egen personlige realisering. Herunder kvindefrigørelsen, ungdomskulturen og moderne familiestrukturer med skilsmisser, papbørn og halvsøskende. Samme holdning løber i Anthony Giddens Intimitetens Forandring (1992). Også Giddens sætter lighedstegn mellem det borgerlige hjem og kernefamilien. Intime relationer har ændret sig og forårsager nu det traditionelle hjems forlis, mener han, og hævder, at i dag er vores forhold til intimitet nemlig kendetegnet ved det, han kalder rene forhold: Familie og intime relationer er 
ikke noget, man går ind i ud fra en foreskreven konvention eller norm, det er noget, som man selv skaber, og derfor selv er med til at opbryde og ændre. Som Kumar konkluderer i sin artikel, så er denne "fragmentering af kernefamilien" ensbetydende med, om end ikke hjemmets sammenbrud, så i hvert fald "fragmentering af hjemmet" (min overs., 1994:228).

Spørgsmålet er, hvad denne og lignende antagelser betyder for vores erfaring af hjem? Både i forhold til vores praktiske hverdag som i relation til overordnede forklaringsmodeller. Kan man overhovedet tale om hjem, når de byggesten, vi skaber hjemmet af, efter sigende er del af en permanent forandringsproces? Og hvordan skal de mange, der stadig holder fast ved idealer som kernefamilien, den eneste ene og det singulære sted, forholde sig til Giddens, Kumar og de mange globaliseringsteoretikere? Og omvendt?

\section{Opgør med globaliseringsretorikken}

Som mediesociolog David Morley skriver i Hometerritories (2000), lever vi i dag i en kultur, der sætter rejsen over hjemmet, kosmopolitten over den lokalt bundne, bevægelse over forankring. ${ }^{6}$ På det overordnede forklaringsniveau har hjemmet mistet sin status som omdrejningspunkt (jf. Bermans splittelse mellem modernisme og modernisering). Det er i hvert fald påfaldende så mange teoretikere, særligt globaliseringstænkere, der indsætter rejsen som metafor for det moderne menneskets grundlæggende vilkår. Schmidt taler i sin undersøgelse af begrebet hjem om, at "livet er blevet en rejse i mere end metaforisk forstand" (Schmidt 2000:273). Bauman går et skridt videre og opdeler det moderne menneske i to rejsekarakterer; nemlig vagabonden og turisten (1998). Mens turisten nyder privilegierne ved en verden, der er i konstant bevægelse, idet han eller hun aktivt selv vælger sine ankomster og opbrud, bliver vagabonden kastet rundt i tilværelsen konkret som mentalt uden ressourcer eller psykologisk overskud til selv at kunne styre sin skæbne. For Bauman, som for mange andre, ligger ambivalensen i indstillingen til moderniteten, ikke så meget som moderniteten i sig selv: Er det (sen)moderne menneske et skib i et hav uden land eller sømærker, så kan vi "enten glæder os over de betagende udsigter til nye oplevelser - eller vi kan ryste af skræk for at drukne“ (1998: 84).

Den underliggende melankoli, som løber sideløbende med euforien i Baumans, som i mange af globaliseringsteoriernes tekster, er netop, hvad sociologen Nikos Papastergiadis har beskæftiget sig med. I Dialogues in the Diasporas (1998) sætter han fokus på, hvad han definerer som globaliseringsteoriernes slagside. En slagside, som kun er blevet mere og mere markant gennem årerne, og som udspringer af tænkningens næsten demonstrative insisteren på forandring, mobilitet og globalisering. Papastergiadis finder nemlig, at ideologien omkring globaliseringen er gennemsyret af forestillingen om det tabte hjem og af stress over den permanente tilstand af hjemløshed, som denne tabserfaring har ført med sig. Forklaringen er, skriver han, at tænkningen er 
groet fast $\mathrm{i}$ en alt for entydig opfattelse af det traditionelle over for det moderne, mobilitet over for forankring. I dette (ofte) stereotypiske univers forstås hjemmet som et rum af komfort "lukket inde i en frossen tid: dømt til uforanderlige konventioner; forbeholdt rene medlemmer; styret af strenge autoritære faderfigurer, undertrykt af religiøse overbevisninger" (Papastergiadis 1998:7, min oversættelse). I kontrast hertil er det moderne kendetegnet ved mobilitet, forandring, udvikling og nedbrydelse af traditioner og myter. En modsætning, som ufrugtbart holder mennesket fast i en mobilitetskultur, pointerer han.

Også Morley sætter fokus på den entydige globaliseringsdiskurs, men fører kritikken et skridt videre ved at påpege, hvorledes opfattelser af globaliseringen ofte ind tager næsten anti-essentielle positioner (2000). ${ }^{7}$ Grunden er, mener Morley, at den ideologi, der indtil nu har defineret globaliseringen, i den grad har romantiseret forskellighederne, mobiliteten og rodløsheden. Hvorfor alt, hvad der har med struktur, system og orden at gøre, betragtes som noget negativt, ja ligefrem sammenlignes med terror, hvis vi skal forfølge antagelsen helt ud i de teorier, der, med en af dekonstruktionens hovedtænkere JeanFrancois Lyotard i spidsen, går i clinch med specielt konsensustanken (2000:232). Dette er grundantagelsen i Lyotards hovedværk The postmodern Condition (1990), som netop er et kampskrift mod konsensus, system og form. I dette, som lignende tænkninger, er der ikke meget plads til overs for hjemmet, hverken på det metaforiske eller det konkrete plan. I alle dets konnotationer er hjemmet indbegrebet af system; og systemet er netop, hvad globaliseringen eller i hvert fald vores kanoniserede fortællinger om den - har bekæmpet, argumenterer Morley (2000:225 - 242).

John Tomlinson er ligeledes skeptisk over for den retorik, der hidtil har domineret diskursen. Den har nemlig overset et fundamentalt problem, hævder han i Globalisation and Culture (1999). Problemet med at tale om mobilitet og globaliseringen som en global erfaring bunder i det faktum, at globaliseringen som sociologi i virkeligheden kun kan appliceres på en lille procentdel af den moderne verden. Det er de færreste, der rent faktisk lever et liv i konstant bevægelse uden et hjem eller et privilegeret sted at referere til. Nok er verden gennemsyret af globaliseringens konsekvenser, men det er stadig det lokale liv, den daglige trummerum, hjemmet og de nære relationer, der optager majoriteten af mennesker verden over, observerer han, og foreslår, at man begynder at se globaliseringen som en proces, der er underlagt hjemmet, og ikke omvendt. Tomlinson elaborerer her videre på ideen om, at globaliseringen fortrinsvis er et resultat af medierne. Er globaliseringen almen, konkluderer han, så er den det ikke i sociologisk forstand, men fordi de fleste mennesker i dag har forestillingen om mobilitet og bevægelsesfrihed. De fleste ved, at muligheden for andre valg foreligger. Derfor, konkluderer Tomlinson, er det fortrinsvis gennem den medieskabte transformation af det lokale liv, og ikke i den faktiske mobilitet, at globaliseringen finder sit mest ekspressive udtryk: "for 
de fleste mennesker er globaliseringens betydning erfaret ikke ved at rejse, men ved at blive hjemme" (Tomlinson 1999:9, min overs.).

Det som Tomlinson, men også Papastergiadis og Morley, forsøger at plædere for, er, at anskue moderniteten gennem den lokalt stedsbundnes øjne, og ikke som man traditionelt har gjort, gennem kosmopolittens. Et sådan perspektivskift er efter min overbevisning en måde at bygge bro over Bermans modernitetskløft mellem modernisme og modernisering, idet den ikke blot redefinerer vores traditionelle opfattelse af hjemmet, men den diskurs, der med udgangspunkt i mobiliteten har haft patent på at beskrive moderniteten.

\section{Fra nostalgisk tilbageskuen til konstruktiv fremtidslængsel}

Hvis den aktuelle interesse for hjem er et udtryk for en genopdagelse af forankring i, hvad Bauman definerer som "en verden af permanent forandring", så rykker det ved vores traditionelle forståelse af hjem, intimitet og hverdagsliv (1998:8). Med andre ord: Hvordan kan man tale om hjem uden at det bliver til en nostalgisk, reaktionær og tilbageskuende proces, der blot er med til at bekræfte den moderne dikotomi mellem forankring og forandring, stilstand og mobilitet?

Det forsøger bl.a. sociologen Lisa Malkki i sin undersøgelse af "National Geographic: The Rooting of Peoples and the Territorialization of National Identity among Scholars and Refugees" (1992). På baggrund af et feltstudie anerkender hun det nostalgiske aspekt i flygtningens beretninger om hjem, men tilføjer, at den falder sammen med en oplevelse af, at flere og flere føler sig rutinemæssigt "fejlplaceret". Hun hævde derfor, at trangen efter et hjem ikke så meget er in situ, som det handler om at skabe en hjemfornemmelse gennem drømme og romantik, uden at denne forestilling bunder i et håb om realisering (Malkki 1992). Også Papastergiadis sætter den nye optagethed af hjem ind i progressive rammer. Næsten i forlængelse af Malkki argumenterer han for, at man måske skulle forsøge at se tidens interesse for hjem og forankring som et "fremtidsorienteret projekt rettet mod konstruktionen af en form for høren-til i en kontekst af forandring og "displacement" "(Papstergiadis 1998:9, min overs.). For både Malkki og Papastergiadis henviser begrebet hjem ikke (nødvendigvis) til et tabt hjem, hvorfor nostalgien ikke behøver at rette sig bagud mod en bedre, men utilnærmelig fortid, den kan pege frem mod en bedre, potentiel fremtid. For Malkkis vedkommende gennem brugbare identitetsskabende fortællinger om hjemmet, for Papastergiadis ved at udvide og opdatere det traditionelle hjembegreb. Også den engelske Wendy Weller retter hjemlængslen mod fremtiden. I artiklen med den underfundige titel "Nostalgia isn't nasty" (1994) lancerer hun begrebet "den postmoderne nostalgi". Hendes pointe er, at man i stedet for at betragte den aktuelle begejstring for hjemmet som et udtryk for sentimentalitet eller som et symptom på tabet af en historisk bevidsthed, skal se den som "et følelsesmæssigt udtryk for en længsel efter fællesskab [community] ${ }^{\text {“ }}{ }^{8}$ Alene fordi, fortsætter hun, at 
det er "mere frugtbart at se den [nostalgien], som et intenst kulturelt udtryk for behovet efter nogle sociale forme, der vil være i stand til at repræsentere det, der er gået tabt i kølvandet på det moderne oplysningsprojekt" (Weller 1994:93-94, min overs.).

\section{Vi hører til mellem rejsen og hjemmet}

Hvis vi skal komme ud over den indbyggede dikotomi mellem rejsen og hjemmet, turisten og vagabonden, må vi forsøge at overkomme nogle af de myter, der ligger i globaliseringsteoriernes selvforståelse som i forståelsen af hjem.

En nærlæsning af både Giddens Intimitetens Forandring og Krishan Kumars allerede citerede artikel rummer faktisk mulighed for en nyfortolkning af forankring, hvis man først er opmærksom på perspektivet. Selv om Giddens diagnosticering af intimitetens vilkår i senmoderniteten har dystre undertoner i forhold til den rationalisering af personligheden, der naturligt følger, når enhver måler hverandre på kvalitet og udbytte, så kan det ikke udelukkes, at de rene forhold godt kan give parterne en fornemmelse af hjemlighed, lige som forholdene godt kan være stabile og langsigtede. For selv om de forskellige relationer ikke nødvendigvis svarer overens med kernefamiliens ideal og ikke har det traditionelle hjems fasttømrede karakter, så kan de sagtens være bygget på tillid, tryghed og tilhørsforhold. Om end inden for de rammer forholdet sætter. Også Kumar åbner mulighed for at udvide hjembegrebet i forhold til følelsen af hjem. I forlængelse af en gennemgang af fordelingen i den britiske befolkning, der lever i og uden for kernefamilien, pointerer han følgende: "figurerne i sig selv siger os ingenting, eller tæet på ingenting, om individernes tilfredsstillelse eller om sundheden i samfundet" (min overs., 1994:223). Implicit forstået, at det klassiske hjem ikke er forbeholdt hjemfølelsen. Hvorfor man - den anden vej rundt - må formode, at ikke-ideelle og ikke anerkendte sociale konstruktioner i lige så høj grad kan være bærere af en fornemmelse for hjem. Pointen er, at det er op til den enkelte selv at docere mellem kravet om forandring og behovet for forankring.

Netop denne forståelse af hjem i et globaliseringsperspektiv, hvor forandring er vilkåret, forsøger filosoffen Agnes Heller at definere i sin artikel "Where are we at home? (1995). Her gør hun op med den indgroede forestilling om hjemmet som stabilitetens locus og lancerer en definition, som er karakteriseret ved sin mobile egenskab. Ifølge Heller har kosmopolitter nemlig også en fornemmelse af forankring og hjemlighed, selv om de er i konstant bevægelse. Akkurat som den lokale stedsbundne opbygger den rejsende et system af gentagelser og vaner, som får hans eller hendes liv til at fremstå kontinuerligt og sammenhængende. Kosmopolitter overnatter på samme hotelkæde, sover i samme side af sengen, ved hvor kontakten til toilettet sidder. De spiser typisk den samme Continential Breakfast og sidder nogenlunde samme sted i flyet, og læser de samme aviser over alt i verden, hvor de befinder sig. Pointen er nemlig, konkluderer Heller, at lige som den lokale stedsbundne gentager kos- 
mopolitten de samme ritualer og vaner, som gør dagen i dag genkendelig og identisk med den forrige, ligeså vel som den peger på og gør morgendagen fortrolig. Forskellen er, at for den lokale stedsbundne udspringer, reproduceres og falder hverdagens cykliske temporalitet tilbage på det singulære sted (den specifikke lokalitet), for kosmopolitten svæver den uforankret i rummet (rummene), den er rodløs. Men til gengæld ikke klaustrofobisk, regressiv eller statisk.

Heller præsenterer et bud på en ny forestilling om hjem, der ikke blot udfordrer vores traditionelle forståelse af hjem, men som ligeledes kræver, at vi må redefinere den klassiske globaliseringsfortælling. Kravet om mobilitet behøver nemlig ikke at udelukke behovet for forankring. I det perspektiv er det derfor mere frugtbart at se den aktuelle interesse for hjem som andet og mere end en nostalgisk tur down memory lane, men som et udtryk for, at globaliseringen også skaber nye muligheder for forankring. De forskellige og ofte modstridende forestillinger om hjem i medier, kunst og litteratur er derfor ikke et udtryk for en rablende laissez faire, men for en eksperimentering. Det vi i øjeblikket oplever i kulturbilledet, på tv og i opgøret med en stereotyp globaliseringsforståelse, er en gennemspilning af forskellige standpunkter omkring, og forestillinger om, hvordan man gør sig det hjemligt i en verden, der er globaliseret. Den næsten demonstrative dyrkelse af "det rigtige hjem" i f.eks. reklamer, serier og magasiner, men også i den nationalpatriotiske retorik, er måske det bedste udtryk for, at kategorierne flyder, at hjemmet ikke længere er noget, som vi tager for givet. I forhold til andre aktuelle gennemspilninger af hjemmet, indtager disse fortalere for det "det rigtige hjem" en næsten desperat position. Men ofte har disse stereotypiske hjem ikke så meget at gøre med virkeligheden, som de er en udforskning af det traditionelle hjems karakteristik med henblik på dannelsen af nye, mere tidssvarende hjemligheder.

Ikke at forstå at vores ambivalente forhold til hjemmet, som har præget det meste af den moderne kulturhistorie, falder bort og kollapser. For hjemmet vil stadig være genstand for både nostalgi og udlængsel og vil stadig kunne bebos med tryghed som med klaustrofobi. Men pointen er, at hjemmet ikke længere repræsenterer et enten-eller og derfor ikke længere repræsenterer en konflikt på det overordnede ideologiske plan. Hjemmet er som alt andet i globaliseringen blevet genstand for forhandling, opløsning, konstruktion og rekonstruktion. Et projekt på lige niveau med alle projekter, noget vi kontant genforholder og reflekterer over. Vi er, med lidt forsigtighed, ved at finde os hjemme i globaliseringen. 


\section{Noter}

1. Om danskernes aktuelle forbrug i boligen, se "Boligdrømme og forbrug", Økonomi og Samfund, årsbog 2007:174-185. København: Forlaget Frydendal.

2. Art \& Craft refererer til en social revolutionær bevægelse i det sene 19. århundrede og tidlige 20. århundredes England med navne som John Ruskin, William Morris og Edwin Lutyens. I en kritik af den begyndelse industrialisering og med middelalderens håndværker som ideal, forsøger designere og tænkere at (gen)skabe et heldhedsforhold mellem mennesket, arbejdet og designet. Helhedstænkning er ligeledes et nøgleord i Ebenezer Howards legendariske værk Garden Cities of To-morrow fra 1902, som introducerer havebyen som alternativ til den moderne, smudsige storby, som ikke er sund for mennesket. Som et lukket, selvkørende system er Howards haveby en sammentænkning af natur og by, og den har som ideal haft stor betydning for moderne by- og boligplanlægning, særligt i de urbane udkantsområder i USA, England og meget af Europa.

3. Surrealisterne var optaget af psykoanalysen og ideen om at mennesket består af psykiske energier, der kan påvirkes positivt eller negativt, heriblandt Sigmund Freuds modernitetskritiske værk Kulturens Byrde fra 1929 (fra org. Das Unbehagen in der Kultur). Mens funktionalisterne med Le Corbusier i spidsen fremhæver maskinen som ideal for hvordan en bolig skal skabes, sætter surrealisterne livmoderen som metafor for idealhjemmet, og efterlyser en arkitektur, der kunne være mere lydhør for psykologiske behov. Anthony Vidler beskriver denne ideologi i artiklen "Homes for Cyborgs" (1986) og citerer den berømte surrealist Tristan Tzara, som ser det som målet at kunne "rekonstruere de cirkulære, kugleformede og irregulære huse, som mennesket har bevaret siden huletiden, fra vugge til grav, $i$ en vision over det intrauterine liv," siger han, og giver herefter funktionalismen dødsstødet "som ikke har noget at gøre med den kastrerede æstetik de kalder moderne" (Vidler 1986:164-65, min overs.)

4. Bl.a. konkluderer forskningsleder Thorkild Ærø sammen med Hans Skifter Andersen og Valinka Suenson i rapporten Bosætning $i$ Ydreområder, at en del af de mennesker, der bosætter sig i udkantsområderne, gør det, fordi de flytter tilbage til deres hjemegn (SBi 2005). I Thorkild Ærøs afhandling Boligprxferencer, boligvalg og livsstil (2002) påpeger han desuden tendensen til at ens boligpræference ligner den man er vokset op med.

5. Se bl.a. Christopher Reeds antologi Not at Home. The suppression of domesticity in Modern Art and Architecture, 1996.

6. Følgende afsnit trækker flittigt på Morleys værk og på mange af de referencer, han selv bruger og reflekterer over.

7. Morleys trækker her specielt på Robert Robbins artikel "Comparative cosmopolitanism". Begrebet anti-essentialist position er dog et af hans egne (Morley 2000:232).

8. Det amerikanske ord "community" dækker over flere konnotationer end det danske "fællesskab", idet det også henviser til fælles sociale livsformer, tilhørsforhold og mindre samfund.

\section{Litteratur}

Baudelaire, Charles 1951: "Det Moderne" Kunstkritik. Overs. Paul la Cour. København: Hasselbachs Forlag.

Bauman, Zygmunt 1998: Globaliseringen. De menneskelige konsekvenser. Cambridge: Polity Press.

Benjamin, Walter 1999/1983: "Louis - Philip, or the Interior". Charles Baudelaire. A Lyric Poet In The Era Of High Capitalism. (1976), overs. Harry Zohn, London: Verso.

Berman, Marshall 1988: All That Is Solid Melts Into Air. USA: Penguin Books.

Chaney, David 1993: Fictions in Collective Life. Public Drama in late modern Culture. London: Routledge. 
Giddens, Anthony 1991/2000: Modernitet og Selvidentitet. Selvet og samfundet under senmoderniteten, overs. Søren Schultz Jørgensen. København: Hans Reitzels Forlag.

Giddens, Anthony 1992/2000: Intimitetens Forandring. Overs. Else Henneberg Pedersen. København: Hans Reitzels Forlag.

Heller, Agnes 1995: "Where are we at home?". Thesis Eleven, 41, 1995:1-18. Massachusett: Massachusett's Institute of Technology.

Homer 1993: Odysseen. Overs. Otto Gelsted. København: Thaning \& Appelts Forlag.

Kumar, Krishan 1994: "Home: The premise and Predicament of Private Life at the end of twentieth century". Public and private in Thought and Practice, (eds. K. Kumar og J. Weintraub), 1994:204-236. Chicago Press, 1994.

Malkki, Lisa 1992: "National Geographic: The Rooting of Peoples and the Territorialization of National Identity among Scholars and Refugees". Cultural Antropology 7 (1), Feb, 1992.

Mechlenborg, Mette 2002: Hjemlighed. Mellem rejsen og hjemmet, speciale, Moderne Kultur, Københavns Universitet.

Morley; David 2000: Home Territories. Media, mobility and identity. London: Routledge.

Papastergiadis, Nikos 1998: Dialogues of Diasporas. Essays and conversations on cultural identity. London: Rivers Oram Press.

Reed, Christopher (ed) 1996: Not at Home. The Suppression of Domesticity in Modern Art and Architecture. London: Thames and Hudson.

Sarup, Madan 1994: "Home and Identity". Travellers' tales. Narratives of Home and Displacement. George Robertson (ed). London: Routledge.

Schmidt, Lars-Henrik 1990/2000: Hjemløshed. Det sociale selv. Invitation til socialanalytik. København: Danmarks Pædagogiske Institut.

Simmel, Georg: Storbyerne og det åndelige liv". Hvordan er samfundet muligt? (19011908), oversat Henning Vagnsgaard1988. København: Gyldendal.

Tomlinson, John 1999: Globalisation and Culture. Cambridge: Polity Press.

Tönnies, Ferdinard 1887/1991: Gemeinschaft und Gesellschaft. Grundbegriffe der Reinen Soziologie. Darmstadt: Wissenschaftliche Buchgesellschaft.

Vidler, Anthony 1996: "Homes for Cyborgs". Not at Home. The Suppression of Domesticity in Modern Art and Architecture, Christopher Reed, (ed.). London: Thames and Hudson.

Weller, Wendy 1994: “Nostalgia Isn't Nasty: The Postmodernising of Parliamentary Democracy“. Altered States. (ed. Mark Perryman). London: Lawrence \& Wishart Limited.

Ærø, Thorkild, Hans Skifter Andersen, Valinka Suenson 2005: Bosætning i Ydreområder. forskningsrapport, Hørsholm: Statens Byggeforskningsinstitut.

Ærø, Thorkild 2002: Boligpræferencer, boligvalg og livsstil. Ph.d.-afhandling. Hørsholm: Statens Byggeforskningsinstitut. 